Prepared for the U.S. Department of Energy under Contract DE-AC05-76RL01830

\title{
Uranium Adsorption on Granular Activated Carbon - Batch Testing
}

\author{
KE Parker \\ EC Golovich \\ DM Wellman
}

September 2013

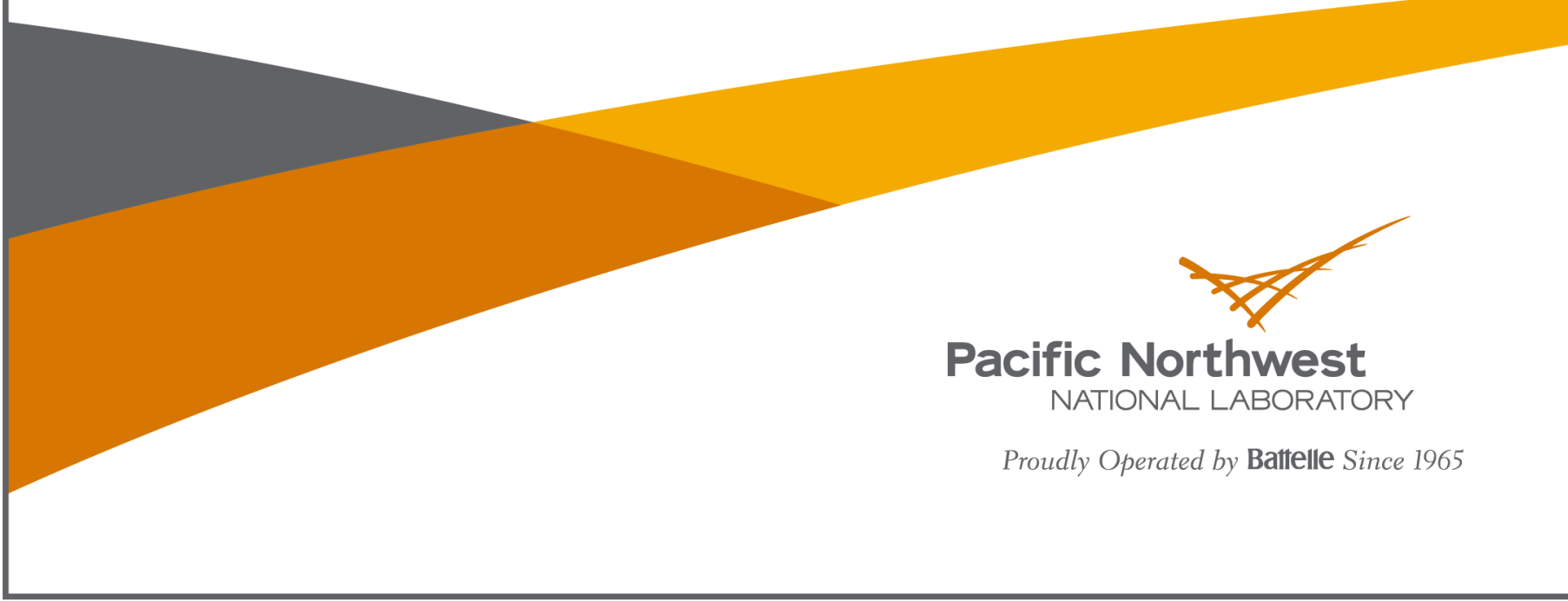




\section{DISCLAIMER}

This report was prepared as an account of work sponsored by an agency of the United States Government. Neither the United States Government nor any agency thereof, nor Battelle Memorial Institute, nor any of their employees, makes any warranty, express or implied, or assumes any legal liability or responsibility for the accuracy, completeness, or usefulness of any information, apparatus, product, or process disclosed, or represents that its use would not infringe privately owned rights. Reference herein to any specific commercial product, process, or service by trade name, trademark, manufacturer, or otherwise does not necessarily constitute or imply its endorsement, recommendation, or favoring by the United States Government or any agency thereof, or Battelle Memorial Institute. The views and opinions of authors expressed herein do not necessarily state or reflect those of the United States Government or any agency thereof.

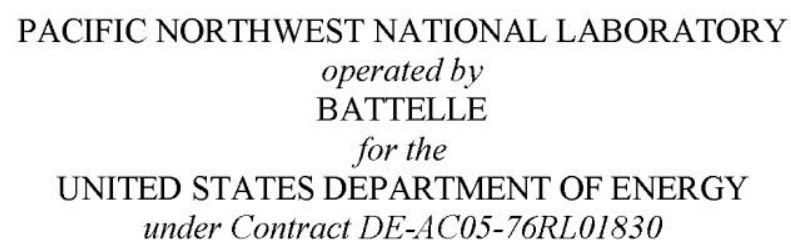

Printed in the United States of America

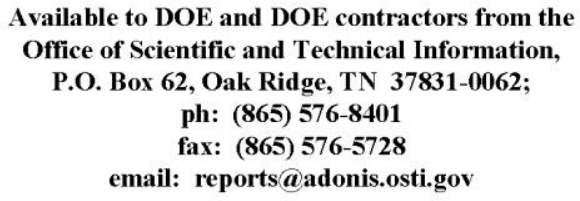




\section{Uranium Adsorption on Granular Activated Carbon - Batch Testing}

KE Parker

EC Golovich

DM Wellman

September 2013

Prepared for

the U.S. Department of Energy

under Contract DE-AC05-76RL01830

Pacific Northwest National Laboratory

Richland, Washington 99352 



\section{Summary}

The uranium adsorption performance of two activated carbon samples (Tusaar Lot B-64, Tusaar ER2189A) was tested using unadjusted source water from well 299-W19-36. These batch tests support ongoing performance optimization efforts to use the best material for uranium treatment in the Hanford Site 200 West Area groundwater pump-and-treat system. A linear response of uranium loading as a function of the solution-to-solid ratio was observed for both materials. $K_{d}$ values ranged from $\sim 380,000$ to $>1,900,000 \mathrm{ml} / \mathrm{g}$ for the B-64 material and $~ 200,000$ to $>1,900,000 \mathrm{ml} / \mathrm{g}$ for the ER2-189A material. Uranium loading values ranged from 10.4 to $41.6 \mu \mathrm{g} / \mathrm{g}$ for the two Tusaar materials. 



\section{Acronyms and Abbreviations}

$\begin{array}{ll}\mu \mathrm{g} & \text { microgram(s) } \\ \mu \mathrm{g} / \mathrm{g} & \text { microgram(s) per gram } \\ \mu \mathrm{m} & \text { micrometer(s) or micron(s) } \\ \mathrm{DOE} & \text { U.S. Department of Energy } \\ \mathrm{EPA} & \text { U.S. Environmental Protection Agency } \\ \mathrm{GAC} & \text { granular activated carbon } \\ \mathrm{ICP}-\mathrm{MS} & \text { inductively coupled plasma-mass spectrometer } \\ \text { OU } & \text { operable unit } \\ \mathrm{K}_{\mathrm{d}} & \text { distribution coefficient(s) } \\ \mathrm{mg} / \mathrm{g} & \text { milligram(s) per gram } \\ \mathrm{mg} / \mathrm{L} & \text { milligram(s) per liter } \\ \mathrm{ml} / \mathrm{g} & \text { milliliters per gram } \\ \mathrm{PNNL} & \text { Pacific Northwest National Laboratory }\end{array}$





\section{Contents}

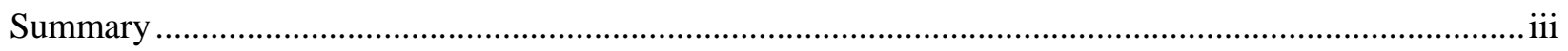

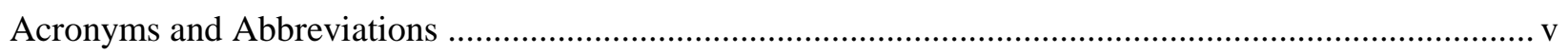

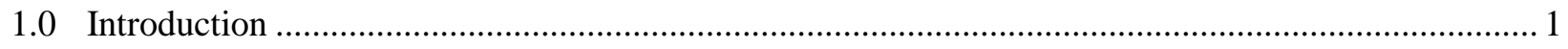

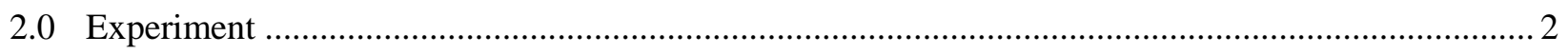

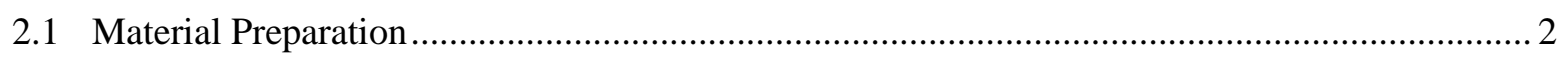

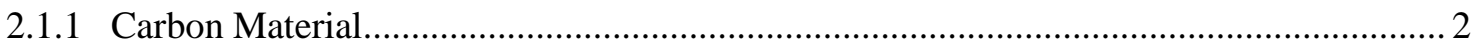

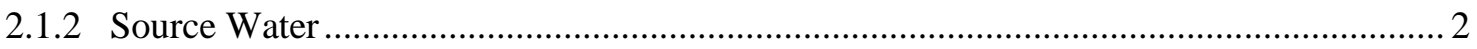

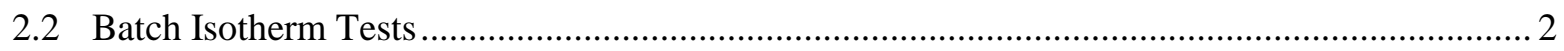

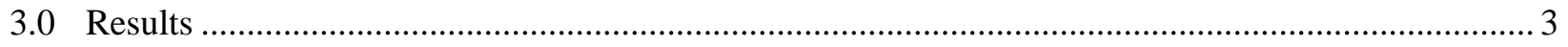

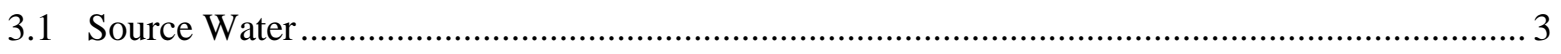

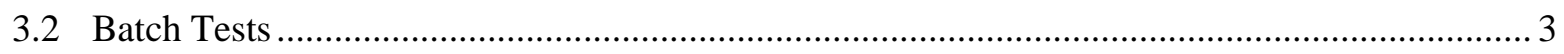

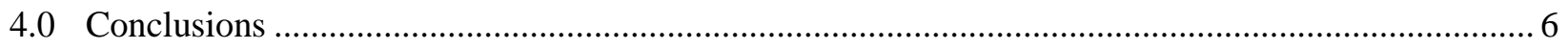

Appendix A Analytes and Analytical Methods ................................................................................. A.1 


\section{Figures}

Figure 3.1. Uranium Loading (mg uranium/g GAC) on Tusaar B-64 GAC as a Function of the Volume-to-Mass Ratio

Figure 3.2. Uranium Loading (mg uranium/g GAC) on Tusaar ER2-189A GAC as a Function of

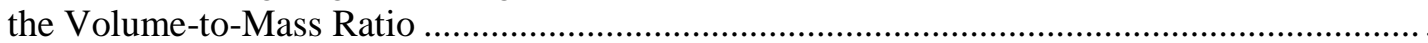

\section{Tables}

Table 3.1. Concentrations of Specified Constituents in 299-W19-36 Source Water................................ 3

Table 3.2. Uranium-Adsorption Data for Tusaar B-64 GAC .............................................................. 3

Table 3.3. Uranium-Adsorption Data for Tusaar ER2-189A GAC ...................................................... 4 


\subsection{Introduction}

CH2M HILL Plateau Remediation Company is currently operating the Hanford Site 200 West Area groundwater pump-and-treat system as the remedial action selected under the Comprehensive Environmental Response, Compensation, and Liability Act Record of Decision for Operable Unit (OU) 200-ZP-1. This report documents the results of treatability tests Pacific Northwest National Laboratory (PNNL) researchers conducted to quantify the ability of selected granular activated carbon (GAC) products to adsorb uranium from 200 West Area groundwater.

Laboratory sorption experiments included batch tests from which the sorption characteristics of each of the GAC materials were quantified. PNNL researchers tested two GAC materials from Tusaar using batch techniques. The goal of the batch testing was to determine the uranium-loading capacity of these materials. 


\subsection{Experiment}

\subsection{Material Preparation}

\subsubsection{Carbon Material}

Carbon material was used as received from Tusaar. The two materials received were B-64 and ER2189A. No additional preparation was required.

\subsubsection{Source Water}

Water from well 299-W19-36 was used for testing. The water was sparged for five days in the original received container to remove any volatile organics. Sparging also lowered the $\mathrm{pH}$ of the water to 7. Water was filtered through a $0.45-\mu \mathrm{m}$ filter before use in the batch tests.

\subsection{Batch Isotherm Tests}

The following resin-to-solution ratios were used for the batch isotherm tests:

- Ratio \#1 - 1.00 g resin/50 ml solution

- Ratio \#2 - $0.75 \mathrm{~g}$ resin/50 ml solution

- Ratio \#3 - 0.50 g resin/50 ml solution

- Ratio \#4 - $0.25 \mathrm{~g}$ resin/50 ml solution.

All batch adsorption tests were conducted for 18 hours. During that time, the centrifuge tubes were agitated continuously at room temperature $\left(22^{\circ} \mathrm{C}\right)$ so the carbon and groundwater remained well mixed. After approximately 18 hours of contact time, the tubes were allowed to stand for five minutes while the carbon settled. A $10-\mathrm{mL}$ sample was obtained and filtered through a $0.45-\mu \mathrm{m}$ filter. The first $5-\mathrm{mL}$ aliquot of filtered sample went back into the sample tube. The second 5-mL aliquot was analyzed for uranium. See Appendix A for a description of analysis procedure. The batch-testing procedure was repeated for each carbon sample. 


\subsection{Results}

\subsection{Source Water}

ICP-MS analyses were conducted on the source water upon receipt to quantify the concentrations of iodine-127, technetium-99, uranium, and nitrate. Results are given in Table 3.1. The analytical error associated with ICP-MS is $\pm 15 \%$.

Table 3.1. Concentrations of Specified Constituents in 299-W19-36 Source Water

\begin{tabular}{ccc}
\hline Constituent & Units & As Received \\
\hline Iodine-127 & $\mu \mathrm{g} / \mathrm{L}$ & 12.2 \\
Technetium-99 & $\mu \mathrm{g} / \mathrm{L}$ & 1.57 \\
Uranium & $\mu \mathrm{g} / \mathrm{L}$ & 197 \\
Nitrate & $\mu \mathrm{g} / \mathrm{mL}$ & 325 \\
\hline
\end{tabular}

\subsection{Batch Tests}

The results of the batch isotherm tests for the Tusaar B-64 carbon material are shown in Table 3.2 and Figure 3.1. Batch isotherm results for the Tusaar ER2-189A carbon material are shown in Table 3.3 and Figure 3.2. For both materials, some of the final uranium concentrations were below the instrument detection limit. These samples are marked with an asterisk in Table 3.2 and Table 3.3. A linear response of uranium loading as a function of the solution-to-solid ratio was observed for both materials as shown in Figure 3.1 for B-64 and Figure 3.2 for ER2-189A. $K_{d}$ values ranged from $~ 380,000$ to $>1,900,000 \mathrm{ml} / \mathrm{g}$ for the B-64 material and $\sim 200,000$ to $>1,900,000 \mathrm{ml} / \mathrm{g}$ for the ER2-189A material. Uranium loading values ranged from 10.4 to $41.6 \mu \mathrm{g} / \mathrm{g}$ for the two Tusaar materials.

Table 3.2. Uranium-Adsorption Data for Tusaar B-64 GAC

\begin{tabular}{|c|c|c|c|c|c|c|}
\hline Sample \# & $\begin{array}{l}\text { U Initial Conc. } \\
(\mu \mathrm{g} / \mathrm{L})\end{array}$ & $\begin{array}{l}\text { U Final Conc. } \\
(\mu \mathrm{g} / \mathrm{L})\end{array}$ & $\begin{array}{c}\text { GAC Mass } \\
(\mathrm{g})\end{array}$ & $\begin{array}{l}\text { Soln. Vol. } \\
\text { (ml) }\end{array}$ & $\begin{array}{l}\text { U Ads. } \\
(\mu \mathrm{g} / \mathrm{g})\end{array}$ & $\begin{array}{c}\mathrm{K}_{\mathrm{d}} \\
(\mathrm{ml} / \mathrm{g})\end{array}$ \\
\hline B64-uranium-pH7-1 & 207.9 & 0.027 & 0.9991 & 50.007 & 10.40 & 381,395 \\
\hline B64-uranium-pH7-2 & 207.9 & 0.027 & 1.0009 & 50.092 & 10.40 & 382,689 \\
\hline B64-uranium-pH7-3 & 207.9 & 0.014 & 0.7491 & 50.015 & 13.88 & 962,942 \\
\hline B64-uranium-pH7-4* & 207.9 & $<0.011$ & 0.7512 & 50.146 & 13.88 & $>1,309,204$ \\
\hline B64-uranium-pH7-5* & 207.9 & $<0.011$ & 0.5002 & 50.013 & 20.79 & $>1,960,946$ \\
\hline B64-uranium-pH7-6* & 207.9 & $<0.011$ & 0.4993 & 49.959 & 20.80 & $>1,962,360$ \\
\hline B64-uranium-pH7-7 & 207.9 & 0.058 & 0.2503 & 50.068 & 41.58 & 717,665 \\
\hline B64-uranium-pH7-8 & 207.9 & 0.042 & 0.2507 & 50.150 & 41.58 & 987,223 \\
\hline \multicolumn{7}{|c|}{$\begin{array}{l}\text { * The final uranium concentrations for these samples were below detection limits; therefore, the quantification limit } \\
\text { of the instrument was used as the "final" concentration of uranium for calculations. } \\
\text { The "U initial conc." was measured on a duplicate sample of source water and is within analytical error of the } \\
\text { previous measurement. }\end{array}$} \\
\hline
\end{tabular}




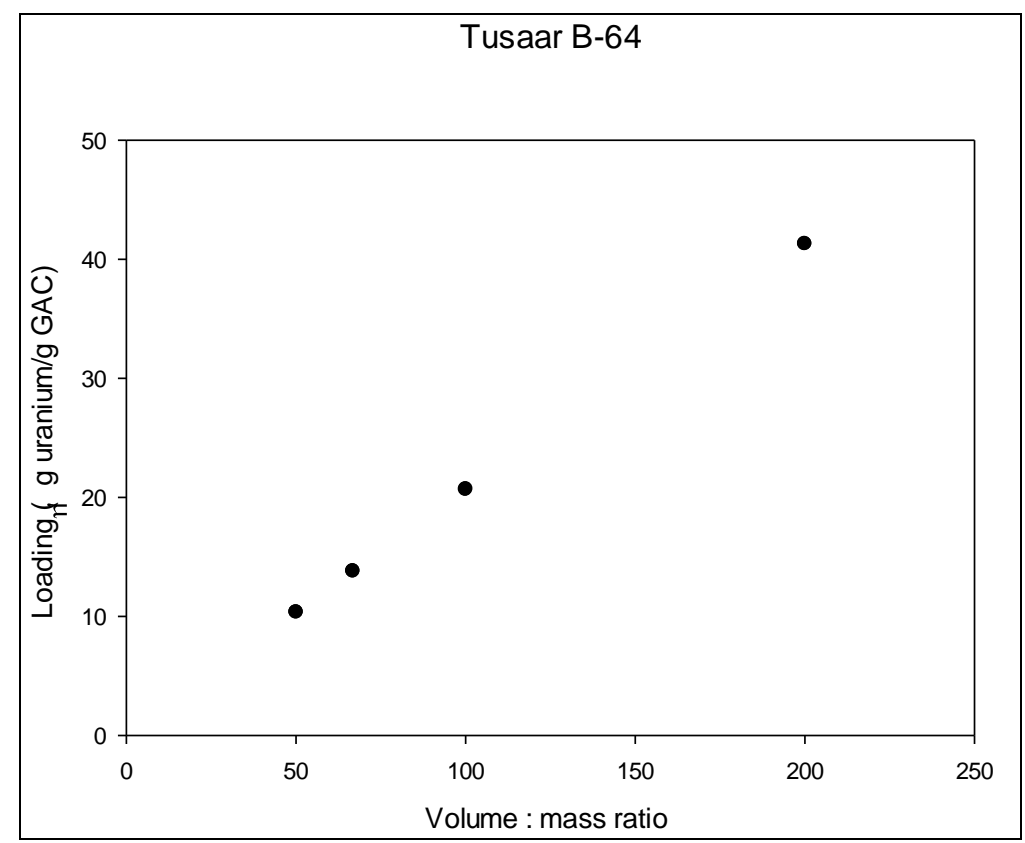

Figure 3.1. Uranium Loading (mg uranium/g GAC) on Tusaar B-64 GAC as a Function of the Volumeto-Mass Ratio

Table 3.3. Uranium-Adsorption Data for Tusaar ER2-189A GAC

\begin{tabular}{llccccc}
\hline \multicolumn{1}{c}{ Sample \# } & $\begin{array}{c}\text { U Initial } \\
\text { Conc. } \\
(\mu \mathrm{g} / \mathrm{L})\end{array}$ & $\begin{array}{c}\mathrm{U} \text { Final Conc. } \\
(\mu \mathrm{g} / \mathrm{L})\end{array}$ & $\begin{array}{c}\text { GAC } \\
\text { Mass }(\mathrm{g})\end{array}$ & $\begin{array}{c}\text { Soln. } \\
\text { Vol. } \\
(\mathrm{ml})\end{array}$ & $\begin{array}{c}\mathrm{U} \text { Ads. } \\
(\mu \mathrm{g} / \mathrm{g})\end{array}$ & $\begin{array}{c}\mathrm{K}_{\mathrm{d}} \\
(\mathrm{ml} / \mathrm{g})\end{array}$ \\
\hline ER2-189A-uranium-pH7-31 & 207.9 & 0.039 & 0.9998 & 50.011 & 10.40 & 265,314 \\
ER2-189A-uranium-pH7-32 & 207.9 & 0.047 & 1.0005 & 50.021 & 10.39 & 219,486 \\
ER2-189A-uranium-pH7-33 & 207.9 & 0.036 & 0.7503 & 50.020 & 13.86 & 386,501 \\
ER2-189A-uranium-pH7-34 & 207.9 & 0.040 & 0.7502 & 50.017 & 13.86 & 348,972 \\
ER2-189A-uranium-pH7-35* & 207.9 & $<0.011$ & 0.5001 & 50.021 & 20.79 & $>1,961,652$ \\
ER2-189A-uranium-pH7-36* & 207.9 & $<0.021$ & 0.5000 & 50.006 & 20.79 & $>980,678$ \\
ER2-189A-uranium-pH7-37 & 207.9 & 0.024 & 0.2505 & 50.109 & 41.58 & $1,744,826$ \\
ER2-189A-uranium-pH7-38 & 207.9 & 0.036 & 0.2503 & 50.061 & 41.57 & $1,145,120$ \\
\hline * The final uranium concentrations for these samples were below detection limits, so the estimated quantification \\
limit of the instrument is given. \\
The "U initial conc." was measured on a duplicate sample of source water and is within analytical error of the \\
previous measurement.
\end{tabular}




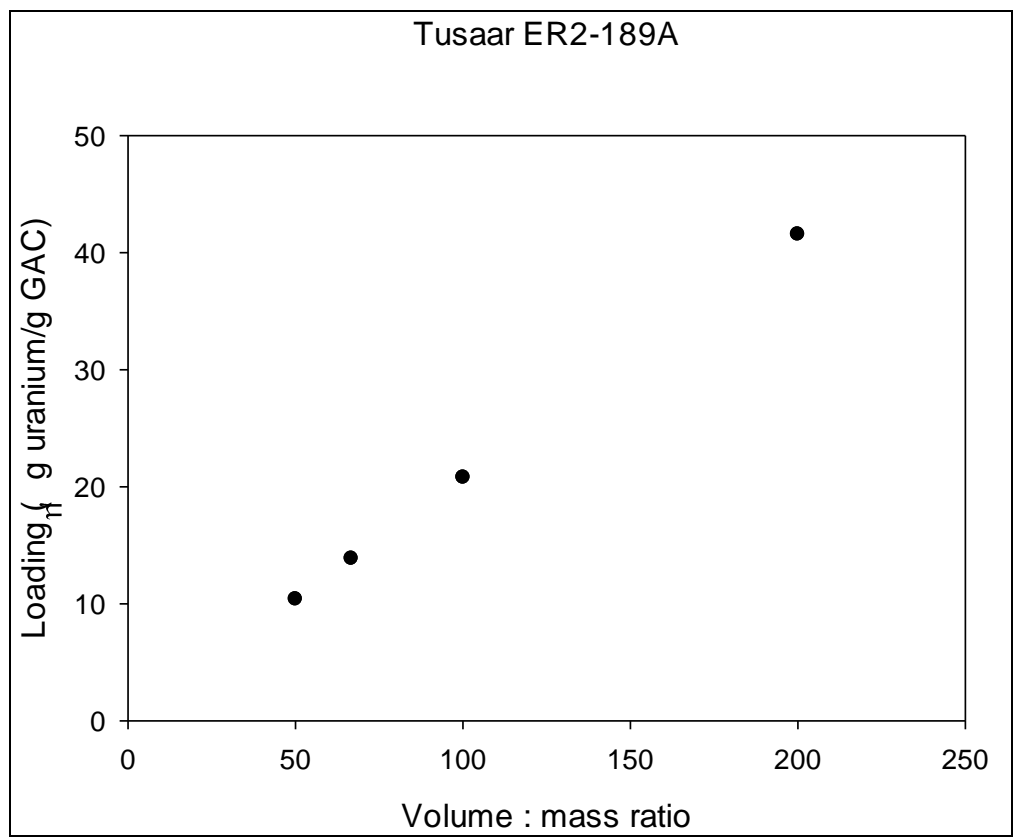

Figure 3.2. Uranium Loading (mg uranium/g GAC) on Tusaar ER2-189A GAC as a Function of the Volume-to-Mass Ratio 


\subsection{Conclusions}

A linear response of uranium loading as a function of the solution-to-solid ratio was observed for both materials. $\mathrm{K}_{\mathrm{d}}$ values ranged from $\sim 380,000$ to $>1,900,000 \mathrm{ml} / \mathrm{g}$ for the B-64 material and $\sim 200,000$ to $>1,900,000 \mathrm{ml} / \mathrm{g}$ for the ER2-189A material. Uranium loading values ranged from 10.4 to $41.6 \mu \mathrm{g} / \mathrm{g}$ for the two Tusaar materials. These results are comparable to previous testing conducted in fiscal year 2011. In these tests, uranium adsorption batch tests were completed on five resin materials (Dowex 1, Dowex 21K 16-30 [fresh], Dowex 21K 16-30 [regenerated], Purofine PFA600/4740, and ResinTech SIR-1200). ${ }^{1}$ The low-nitrate tests from that work had similar test conditions to the current experiments. The $\mathrm{K}_{\mathrm{d}}$ values for Dowex 1 and Dowex 21K 16-30 (fresh) ranged from approximately 800,000 to 1,500,000 ml/g. Purofine PFA600/4740 and ResinTech SIR-1200 resins had $\mathrm{K}_{\mathrm{d}}$ values that ranged from $~ 800,000$ to $3,500,000 \mathrm{ml} / \mathrm{g}$. The regenerated Dowex $21 \mathrm{~K} 16-30$ resin exhibited attenuated uranium-adsorption performance with $\mathrm{K}_{\mathrm{d}}$ values ranging from 15,000 to $34,000 \mathrm{ml} / \mathrm{g}$. Uranium loading values ranged from 8 to $37 \mu \mathrm{g} / \mathrm{g}$ for the resins.

\footnotetext{
${ }^{1}$ Mattigod SV, EC Golovich, DM Wellman, EA Cordova, and RM Smith. 2010. Uranium Adsorption on IonExchange Resins - Batch Testing. PNNL-20135, Pacific Northwest National Laboratory, Richland, WA.
} 


\section{Appendix A}

\section{Analytes and Analytical Methods}





\section{Appendix A}

\section{Analytes and Analytical Methods}

The analytes and analytical methods for the testing are described below.

\section{A.1 Analyte List}

Influent water was analyzed for uranium, technetium-99, and nitrate. Batch contact solutions were analyzed for uranium only.

\section{A.2 Trace Metals Analysis}

Iodine-127, uranium, and technetium-99 analyses of the groundwater/test solution were performed using an inductively coupled plasma-mass spectrometer (ICP-MS) following procedure PNNL-AGG-415, "Inductively Coupled Plasma Mass Spectrometry (ICP-MS) Analysis,", which is similar to SW-846, Method 6020A (EPA 1996). High-purity traceable single element standards traceable to the National Institute of Standards and Technology (Ultra Scientific [(Kingston, RI] and Inorganic Ventures [Lakewood, New Jersey]) were used to generate calibration curves and to verify continuing calibration during the analytical run. A serial dilution was made of select samples to investigate and correct for matrix interferences. Typical instrument detection limits for the ICP-MS are in the range of parts per trillion.

\section{A.3 Anion Analysis}

Anion analyses of the groundwater was performed using PNNL's procedure AGG-IC-001, "Determinations by Ion Chromatography (IC),"2 which is similar to EPA SW-846, Method 9056A (EPA 2007). Nitrate was separated on a Dionex AS18 column with a sodium hydroxide gradient elution and measured using a conductivity detector. The only modification to the EPA ion-chromatography method was the use of sodium hydroxide for gradient elution. High-purity calibration standards were used to generate calibration curves and to verify continuing calibration during the analytical run.

\footnotetext{
${ }^{1}$ Clayton ET. 2008. "Inductively Coupled Plasma Mass Spectrophotometry (ICP-MS)," PNNL-AGG-415, unpublished PNNL Technical Procedure, Pacific Northwest National Laboratory, Richland, Washington.

${ }^{2}$ Lindberg MJ. 2004. "Determinations by Ion Chromatography (IC),” AGG-IC-001, unpublished PNNL Technical Procedure, Pacific Northwest National Laboratory, Richland, Washington.
} 


\section{A.4 References}

U.S. Environmental Protection Agency (EPA). 1996. "Method 6020A, Inductively Coupled Plasma Mass Spectrometry," Rev. 1. In Test Methods for Evaluating Solid Waste: Physical/Chemical Methods.

U.S. Environmental Protection Agency (EPA). 2007. "Method 9056A, Determination of Inorganic Anions by Ion Chromatography," Rev. 1. In Test Methods for Evaluating Solid Waste: Physical/ Chemical Methods. EPA SW 846, EPA Office of Solid Waste and Emergency Response,

Washington, D.C. Accessed January 11, 2011 at http://www.epa.gov/wastes/hazard/testmethods/ sw846/pdfs/9056a.pdf. 


\section{Distribution}

No. of

Copies

\# John Morse

Department of Energy - Richland Office

825 Jadwin Ave

Richland, WA 99354
No. of

\section{Copies}

\section{\# Local Distribution}

Pacific Northwest National Laboratory

Elizabeth Golovich

(PDF)

Kent Parker

(PDF)

Dawn Wellman 




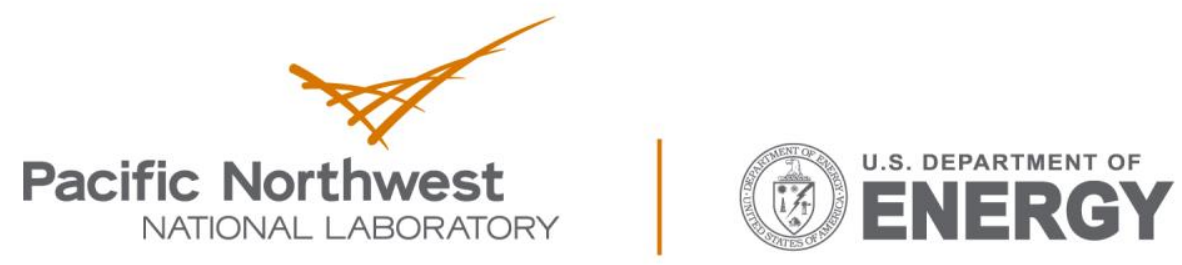

Proudly Operated by Battelle Since 1965

902 Battelle Boulevard

P.O. Box 999

Richland, WA 99352

1-888-375-PNNL (7665)

www.pnnl.gov 